\title{
Diallel Analysis of High Carotenoid Content in Cucumbers
}

\author{
John P. Navazio ${ }^{1}$ and Philipp W. Simon ${ }^{2}$ \\ U.S. Department of Agriculture, Agricultural Research Service, Vegetable Crops Research Unit, \\ Department of Horticulture, University of Wisconsin, Madison, WI 53706
}

\begin{abstract}
AdDITIONAL INDEX wORDS. quantitative inheritance, vegetable breeding, vitamin A, Cucumis sativus
Abstract. Three orange-mesocarp derivatives of the xishuangbannan cucumber (Cucumis sativus L. var. xishuangbannanesis Qi et Yuan), P100, P101, and P104; and NPI (P105), an unrelated cucumber (Cucumis sativus L.)reported to have orange flesh, were selected as parents for a diallel experiment to evaluate inheritance of orange cucumber mesocarp pigment over 3 years. Visual color intensity and carotenoid content were closely related. A preponderance of additive genetic effects for cucumber mesocarp pigmentation was observed in grade size 2 fruit (immature fruit used for pickling). Both additive and nonadditive genetic effects were important in grade size 4 fruit (mature). Years and year $\times$ genotype interactions were highly significant for pigmentation of size 2 fruit, indicating the importance of environment on the expression of pigmentation in this size class. In contrast, color development was stable among years for size 4 fruit. P104 exhibited high general combining ability (GCA) estimates for size 4 fruit pigmentation across years, while P101 had high GCA estimates for size 2 fruit. The diallel analysis illustrated high fruit carotene content of parents per se. However, most hybrid combinations of the diallel reduced carotenoid content relative to parents, indicating both dominance for low carotenoid content for both fruit sizes and lack of genetic complementation among parents to enhance fruit color. Genetic control of pigmentation in size 2 fruit appeared to be independent of that for size 4 fruit.
\end{abstract}

The importance of horticultural crops as sources of vitamins and minerals in the human diet has long been recognized (Munger, 1988; Senti and Rizek, 1975; Steenbock and Gross, 1919). After protein-energy malnutrition, vitamin A deficiency is cited most often as having the greatest impact on human health (World Bank, 1993). The World Health Organization (WHO, 1995) calculated that 3 million children have clinical signs of vitamin A deficiency while another 250 million have subclinical deficiency. On a worldwide basis orange, red, yellow, and dark green vegetables and fruit account for most of the vitamin A consumed, in the form of provitamin A carotenoids (WHO, 1995), and concentrations in food of as low as $2 \mathrm{mg} \cdot \mathrm{kg}^{-1}$ are considered significant (Ye et al., 2000).

Several crops in the Cucurbitaceae including squash [Cucurbita maxima Duch. ex Lam. and C. moschata (Duch. ex Lam.) Duch. ex Poir.], pumpkins (C. pepo L.), and melons (Cucumis melo L.) are vegetable sources of vitamin A (Simon, 1990), with high levels of mesocarp carotenoids in some cultivars. In contrast to other cucurbits, the overwhelming majority of cucumber ( $\mathrm{CuCu}$ mis sativus) germplasm has mesocarp tissue with little or no pigmentation. Because cucumber is the fourth most economically important vegetable (Tatlioglu, 1993) and grown on over 1.5 million hectares for pickling or fresh consumption in nearly all countries (FAO, 1998), the development of cucumbers as a provitamin A carotenoid source could have nutritional significance in vitamin A deficient regions of the world.

Kooistra (1971) was the first researcher to report yellow or orange cucumber fruit flesh color in the mature fruit of an inbred line, designated NPI, derived from the cross 'Natsufushinari' X PI

Received for publication 24 Jan. 2000. Accepted for publication 12 Sept. 2000 This research was funded in part by the Pickle Seed Research Foundation, Pickle Packers International and the University-Industry Relations, at the University of Wisconsin-Madison.The cost of publishing this paper was defrayed in part by the payment of page charges. Under postal regulations, this paper therefore must be hereby marked advertisement solely to indicate this fact.

${ }^{1}$ Former graduate student, Plant Breeding and Plant Genetics Program. Current address: Alf. Christianson Seed Co., P.O. Box 1788, Mount Vernon, WA 98273.

${ }^{2}$ Research geneticist and professor; corresponding author.
200815 from Burma. Qi et al. (1983) first characterized the Xishuangbannan cucumber (C. sativus L. var.xishuangbannanesis Qi et Yuan) (XIS), a Chinese landrace that exhibits orange fruit flesh pigmentation at full seed maturity. The Xishuangbannan cucumber is readily intercrossed to the common cultivated cucumber, sharing the same chromosome number $(2 n=2 x=14)$. In breeding experiments with XIS, Qi et al. (1983) reported this orange-fleshed pigmentation trait to be a simple monogenic dominant when crosses were made to common white-fleshed Chinese cucumbers.

We have recently developed derivatives of the XIS in U.S. pickling backgrounds that express orange fruit flesh pigmentation at full seed maturity as well as the commonly utilized immature state (Simon and Navazio, 1997). Thus, the objective of this study was to investigate the combining ability of the orange pigmentation trait in these derivatives. In initial $\mathrm{F}_{1}, \mathrm{~F}_{2}$, and $\mathrm{BC}_{1}$ progeny generated from crosses between XIS and 12 different U.S. pickling cucumber cultigens, orange pigmentation was not expressed in all pickling cucumber backgrounds but it was observed in derivatives of Wisconsin SMR 18 (Walker, 1958) and 'Addis', and then only with considerable variation, suggesting control by more than one locus and/or reduced penetrance (Simon and Navazio, 1997).

Moll and Stuber (1974) suggested use of the diallel for early generation testing of segregating materials extracted from a population, such as XIS derivatives. Diallel crosses are a valuable tool for selecting materials with good general combining ability and generating elite breeding populations. With the availability of high carotenoid germplasm from Kooistra's study (1971) as well as our recent selection derived from XIS, a diallel analysis was therefore chosen to evaluate the genetic nature and combining ability of carotenoid pigmentation in cucumbers.

\section{Materials and Methods}

Plant material. In Spring 1991, a 4 x 4 diallel crossing block was initiated in the greenhouse. Two of the parents used were derived from matings of XIS with Wisconsin SMR 18, with two 
(P100) and three (P104) generations of sibmating after a backcross to XIS (Simon and Navazio, 1997). The third parent (P101) was derived from a mating of XIS with 'Addis' with three generations of sibmating after a backcross to XIS. The fourth parent, NPI (P105), was an inbred line reported to express orange pigmentation in mature fruit mesocarp tissue (Kooistra, 1971). The four diallel parents included were designated:

1) $\mathrm{P} 100=[($ Wis. SMR $18 \times \mathrm{XIS}) \times \mathrm{XIS}] \mathrm{BC}_{1} \mathrm{M}_{2}$

2) $\mathrm{P} 101=[($ 'Addis' $\times \mathrm{XIS}) \times \mathrm{XIS}] \mathrm{BC}_{1} \mathrm{M}_{3}$

3) $\mathrm{P} 104=[($ Wis. SMR $18 \times \mathrm{XIS}) \times \mathrm{XIS}] \mathrm{BC}_{1} \mathrm{M}_{3}$

4) $\mathrm{P} 105=\mathrm{NPI} \mathrm{F}_{5}$

In Summer 1991, 1992, and 1993, seeds of the four parents and all six progeny of the half-diallel, with three reciprocal cross progeny (P100 x P104, P101 x P105, and P104 x P105), were sown in a randomized complete block design. Six to seven plants for each entry were included in each of three replications at the University of Wisconsin Agricultural Research Station, West Madison, on a Plano silt loam soil (fine-silty, mixed, mesic Typic Argiudoll). For ease of locating individual plants, parents and progeny were grown in $1.0 \times 1.0 \mathrm{~m}$ hills, $3.0 \mathrm{~m}$ between hill centers in a rectangular grid, two adjacent hills comprised a replication, with four to six plants per hill in 1991. Two hills for each accession were randomized in three blocks. To use less field space in 1992 and 1993, plants were grown in $4.0 \mathrm{~m}$ long single rows spaced $1.8 \mathrm{~m}$ apart with one row per accession per block. Each accession row was randomized within each of three blocks in these latter 2 years. In all years, plants were spaced 15 to $20 \mathrm{~cm}$ apart. Standard fertilization, pest control, and cultivation practices were utilized in all experiments (Staub and Bacher, 1997).

Visual AND LABORATORY EVALUATION OF COLOR. Fruit from diallel parents and progeny were evaluated throughout the growing seasons for color at two different sizes that correspond to standard size classes recognized by the U.S. pickling industry. These size classes are based upon fruit diameter: size $2=27 \mathrm{~mm}$ to $38 \mathrm{~mm}$; and size $4=51$ to $54 \mathrm{~mm}$ (includes mature seed) (U.S. Dept. Agr., 1966). Sizes 1, 2, and 3 fruit are most important for commercial production of pickled cucumbers, and size 4 has been evaluated in reports of expression of the orange-flesh mesocarp trait in mature fruit of the Xishuangbannan cucumber (Chen et al., 1994, Qi et al., 1983, Yang et al., 1991). Harvest of fruit for size 4 was done as late in the season as possible before fruit damage from frost, that occurred in the last week of September 1991 and 1992, and in the second week of October 1993. For each plant, six to eight fruit of each size were evaluated visually. Of these, two were selected at random for spectrophotometric evaluation.

Mesocarp color was classified visually as: $\mathrm{W}=$ white, $\mathrm{Gr}=$ green, $\mathrm{Or}=$ orange, and $\mathrm{Y}=$ yellow, with intensities of each class designated as; $\mathrm{vp}=$ very pale, $\mathrm{p}=$ pale, $\mathrm{d}=$ dark, or $\mathrm{vd}=$ very dark. In some P101 derivatives with early expression of mesocarp pigmentation, color classes $\mathrm{YGr}=$ yellow-green and $\mathrm{OrGr}=$ orange-green were also used to describe the blend of color observed. Their names from the Horticultural Colour Chart (The British Colour Council and the Royal Horticultural Society, 1938) are listed in Table 1. To establish a relationship between carotenoid content and color, a diverse subset of samples $(\approx 30 \%$ of the samples for each plant) was measured both visually and by laboratory analyses, including spectrophotometric analysis of total carotenoids, and high-performance liquid chromatography (HPLC) quantification of individual pigments (Table 1).

Fruit SAMPling fOr laboratory eVAluation. Cucumbers were harvested and mesocarp samples (two per fruit) frozen within $72 \mathrm{~h}$ of harvest. Frozen samples were lyophilized and stored at $22^{\circ} \mathrm{C}$ in sealed bags until carotene extraction. Carotene content of hexane extracts was quantified spectrophotometrically with HPLC separation as described by Simon and Wolff (1987). Samples for carotene extraction from size 2 fruit included the entire mesocarp region since pigmentation was uniformly distributed. However, pigmentation was frequently not uniformly dis-

Table 1. Visual rating categories, mean carotenoid content $\left(\mathrm{mg} \cdot \mathrm{kg}^{-1} \mathrm{FW}\right)$, and Horticultural Colour Chart (The British Colour Council and The Royal Horticultural Society, 1938) designations of cucumbers among several inbreds and their hybrids.

\begin{tabular}{|c|c|c|c|c|c|c|}
\hline \multirow[b]{2}{*}{$\begin{array}{l}\text { Visual } \\
\text { flesh } \\
\text { color }^{\mathrm{z}}\end{array}$} & \multicolumn{2}{|c|}{$\begin{array}{l}\text { Fruit sizes } 2 \text { and } 4 \text {, } \\
\text { parent P101, } \\
\text { and its hybrids }\end{array}$} & \multicolumn{2}{|c|}{$\begin{array}{l}\text { Fruit size } 2, \\
\text { parents } \mathrm{P} 100 \text { and } \mathrm{P} 104, \\
\text { and their hybrids }\end{array}$} & \multicolumn{2}{|c|}{$\begin{array}{l}\text { Fruit size } 4, \\
\text { parents } \mathrm{P} 100 \text { and } \mathrm{P} 104, \\
\text { and their hybrids }\end{array}$} \\
\hline & $\begin{array}{l}\text { Mean } \\
\text { carotenoid } \\
\text { content } \\
\left(\mathrm{mg} \cdot \mathrm{kg}^{-1}\right)^{\mathrm{y}}\end{array}$ & $\begin{array}{l}\text { Horticultural } \\
\text { Colour Chart } \\
\text { designation }\end{array}$ & $\begin{array}{l}\text { Mean } \\
\text { carotenoid } \\
\text { content } \\
\left(\mathrm{mg} \cdot \mathrm{kg}^{-1}\right)\end{array}$ & $\begin{array}{l}\text { Horticultural } \\
\text { Colour Chart } \\
\text { designation }\end{array}$ & $\begin{array}{l}\text { Mean } \\
\text { carotenoid } \\
\text { content } \\
\left(\mathrm{mg} \cdot \mathrm{kg}^{-1}\right)\end{array}$ & $\begin{array}{l}\text { Horticultural } \\
\text { Colour Chart } \\
\text { designation }\end{array}$ \\
\hline$\overline{\mathrm{dOr}}$ & & & & & $13.2 \mathrm{a}$ & Saffron Yellow 7/1 \\
\hline dY & & & & & $5.6 \mathrm{ab}$ & Lemon Yellow 4/2 \\
\hline $\mathrm{OrGr}$ & $3.1 \mathrm{a}$ & $\mathrm{Or}+\mathrm{YGr}$ & & & & \\
\hline Or & $2.5 \mathrm{ab}$ & Uranium Green 63 & & & $4.2 \mathrm{~b}$ & Saffron Yellow 7/2 \\
\hline YGr & $2.5 \mathrm{ab}$ & Saffron Yellow 7/2 & $3.7 \mathrm{a}$ & Uranium Green 63/1 & & \\
\hline $\mathrm{Y}$ & & & & & $1.7 \mathrm{c}$ & Lemon Yellow 4/2 \\
\hline pOr & $1.5 \mathrm{c}$ & Indian Yellow 6/2 & & & $1.7 \mathrm{c}$ & Apricot 609/2 \\
\hline $\mathrm{Gr}$ & $1.7 \mathrm{bc}$ & Sap Green 62/2 & $1.8 \mathrm{a}$ & Sap Green 62/2 & $0.9 \mathrm{~cd}$ & Uranium Green 63/1 \\
\hline pYGr & $1.6 \mathrm{c}$ & Uranium Green 63/2 & $0.8 \mathrm{~b}$ & Chartreuse Green 66/3 & & \\
\hline pOrGr & $1.5 \mathrm{c}$ & $\mathrm{pOr}+\mathrm{pYGr}$ & & & & \\
\hline vpOr & $0.8 \mathrm{~d}$ & Chinese Yellow 606/2 & & & $0.5 \mathrm{~d}$ & Saffron Yellow 7/3 \\
\hline pY & & & $0.7 \mathrm{~b}$ & Dresden Yellow 64/2 & $0.5 \mathrm{~d}$ & Aureolin $3 / 2$ \\
\hline pGr & $0.5 \mathrm{e}$ & Uranium Green 63/2 & $0.5 \mathrm{~b}$ & Uranium Green 63/2 & $0.4 \mathrm{~d}$ & Uranium Green 63/2 \\
\hline W & & & $0.2 \mathrm{c}$ & --- & $0.1 \mathrm{e}$ & --- \\
\hline
\end{tabular}

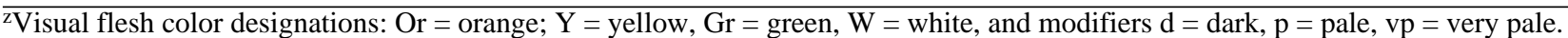
${ }^{\mathrm{y}}$ Geometric mean (antilog of $\log \mathrm{mg} \cdot \mathrm{kg}^{-1}$ mean value); values in each column followed by the same letter are not significantly different at $P \leq 0.05$ on a least squares $\log _{10}$ basis.
} 
Table 2. Summary statistics for visual carotenoid values converted to equivalent $\mathrm{mg} \cdot \mathrm{kg}^{-1} \times 100$ (fresh weight) in size 2 and size 4 fruit for a four parent cucumber halfdiallel with parents in 1991, 1992, and 1993.

\begin{tabular}{|c|c|c|c|c|c|c|c|c|c|c|c|c|c|c|c|c|}
\hline \multirow{3}{*}{$\begin{array}{l}\text { Female } \\
\text { parents }\end{array}$} & \multicolumn{4}{|c|}{ Over all 3 years } & \multicolumn{12}{|c|}{ By individual year } \\
\hline & \multicolumn{4}{|c|}{ Male parents } & \multicolumn{3}{|c|}{ P100 } & \multicolumn{3}{|c|}{ P101 } & \multicolumn{3}{|c|}{ P104 } & \multicolumn{3}{|c|}{ P105 } \\
\hline & P100 & P101 & P104 & P105 & 1991 & 1992 & 1993 & 1991 & 1992 & 1993 & 1991 & 1992 & 1993 & 1991 & 1992 & 1993 \\
\hline \multicolumn{17}{|l|}{ P100 } \\
\hline size 2 & $51 \pm 9^{z}$ & & & & $77 \pm 19$ & $36 \pm 3$ & $41 \pm 2$ & & & & & & & & & \\
\hline size 4 & $80 \pm 25$ & & & & $119 \pm 78$ & $48 \pm 12$ & $76 \pm 3$ & & & & & & & & & \\
\hline \multicolumn{17}{|l|}{ P101 } \\
\hline size 2 & $50 \pm 11$ & $160 \pm 9$ & & & & $33 \pm 7$ & $31 \pm 1$ & $86 \pm 21$ & $140 \pm 9$ & $152 \pm 8$ & $190 \pm 9$ & & & & & \\
\hline size 4 & $22 \pm 2$ & $97 \pm 7$ & & & & $27 \pm 1$ & $16 \pm 1$ & $23 \pm 3$ & $79 \pm 7$ & $91 \pm 5$ & $122 \pm 8$ & & & & & \\
\hline \multicolumn{17}{|l|}{ P104 } \\
\hline size 2 & $33 \pm 4$ & $55 \pm 8$ & $45 \pm 7$ & & $35 \pm 8$ & $35 \pm 9$ & $29 \pm 4$ & $80 \pm 11$ & $31 \pm 3$ & $55 \pm 2$ & $68 \pm 9$ & $33 \pm 6$ & $35 \pm 3$ & & & \\
\hline size 4 & $49 \pm 9$ & $19 \pm 1$ & $152 \pm 24$ & & $27 \pm 5$ & $44 \pm 16$ & $74 \pm 7$ & $23 \pm 3$ & $18 \pm 1$ & $17 \pm 1$ & $195 \pm 55$ & $105 \pm 29$ & $157 \pm 32$ & & & \\
\hline \multicolumn{17}{|l|}{ P105 } \\
\hline size 2 & $38 \pm 8$ & $30 \pm 5$ & $35 \pm 5$ & $29 \pm 4$ & $58 \pm 22$ & $27 \pm 1$ & $29 \pm 1$ & $46 \pm 10$ & $23 \pm 1$ & $22 \pm 3$ & $46 \pm 10$ & $25 \pm 2$ & $34 \pm 3$ & $46 \pm 5$ & $21 \pm 1$ & $21 \pm 1$ \\
\hline size 4 & $22 \pm 2$ & $19 \pm 2$ & $20 \pm 4$ & $15 \pm 1$ & $24 \pm 3$ & $20 \pm 3$ & $24 \pm 3$ & $24 \pm 5$ & $17 \pm 1$ & $16 \pm 1$ & $25 \pm 12$ & $20 \pm 2$ & $16 \pm 1$ & $16 \pm 3$ & $13 \pm 1$ & $16 \pm 1$ \\
\hline
\end{tabular}

${ }^{\mathrm{z} M e a n}+\mathrm{SE}$.

tributed in mature size 4 fruit. Therefore endocarp, inner mesocarp, outer mesocarp, and exocarp tissues were sampled separately when differences in color were observed. The endocarp and inner mesocarp ( 6 to $8 \mathrm{~mm}$ region adjacent to the endocarp) were sites of highest pigmentation. To determine the relative contribution of each of these four tissue categories to the overall interior flesh of the mature cucumber, an average percentage weight of each tissue type was determined from 31 individual size 4 cucumbers chosen randomly during the course of sampling. In mature size 4 fruit, seeds were separated from endocarp tissue and disposed of before the endocarp was weighed. Outer mesocarp tissue accounted for $45.9 \%$ (SE 6.6), inner mesocarp for 33.8\% (SE 6.4), endocarp for $13.6 \%$ (SE 5.4), and exocarp for 6.7\% (SE 2.7) of fruit fresh weight $(\mathrm{FW})$. These percentages were used to calculate total carotenoid content for size 4 individual cucumbers. Occasional samples of mesocarp tissue from nonpigmented fruit were taken as a control for laboratory analyses.

Statistical analysis. Because HPLC analysis could not be performed on all fruit produced in this study, the relationship was studied between visual mesocarp classification of cucumber color and total carotenoid values as measured spectrophotometrically on $\approx 30 \%$ of the fruit evaluated visually. We used family and color as factors in all analyses in general linear model analysis of variance (ANOVA) (SAS Inst. Inc., 1990). To stabilize the variance, a $\log 10$ transformation was used before performing ANOVA (Snedecor and Cochran, 1980). A pairwise comparison was performed to distinguish least squares mean estimates between color classes. Resulting means were converted back to original milligrams per kilogram units with the antilog function, 10 LS Mean value $=$ mean millgrams per kilogram carotenoids. All carotenoid concentrations were calculated and reported on a FW basis.

For diallel analyses, parents and crosses were considered fixed effects. Estimates of general combining ability (GCA) and specific combining ability (SCA) in 1991, 1992, and 1993 for 4 x 4 half diallels with parents were obtained using Griffing's (1956) experimental method 2, model 1 . This fixed effects model includes parents but not reciprocal crosses.

Reciprocal differences were tested in 1991 and 1993 with a complete $3 \times 3$ subset (P101, P104, and P105) of the $4 \times 4$ halfdiallel using method 1 , model 1 of Griffing (1956). Because year effects are random and genotype effects are fixed, year $\times$ GCA, year $\times$ SCA, and year $\times$ reciprocal interactions were used to test significance of GCA, SCA, and reciprocal effects, respectively, when those interactions were significant.

\section{Results}

ESTIMATION OF CAROTENE CONTENT FROM VISUAL VALUES. Because laboratory analysis of the large number of samples generated $(\approx 3500$ per year) was not feasible, use of visual observations was necessary (Table 1). In all cases, color intensity correlated with carotenoid content. Some visually different colors had similar carotenoid content. For example pGr, pY, and vpOr size 4 fruit of P100 and P104, Wisconsin SMR 18 derivatives, had comparable carotenoid content. P101 from 'Addis' X XIS, and its hybrids, expressed a different set of visual mesocarp colors than P100 and P104. Interestingly, we were able to combine fruit of sizes 2 and 4 from P101 for comparison of visual color with analytical lab values due to nonsignificant differences in the color-carotenoid relationship. In contrast, the color-carotenoid relationship differed between sizes 2 and 4 fruit in derivatives of Wisconsin SMR $18 \times$ XIS. Fruit with YGR, Or, OrGr, dY or dOr flesh color had over $2 \mathrm{mg} \cdot \mathrm{kg}^{-1}$ carotenoid content. Through the use of these tables, visual scores of all fruit scored in the diallel were

Table 3. Model and diallel ANOVA for visual carotenoid values in a four parent cucumber half-diallel with parents over 3 years for size 2 and size 4 fruit.

\begin{tabular}{lrcc}
\hline \hline & & \multicolumn{2}{c}{ Mean square } \\
\cline { 3 - 4 } Source & df & Size 2 & Size 4 \\
\hline Year & 2 & $0.36^{* *}$ & $0.25^{\mathrm{NS}}$ \\
Rep (year) & 6 & $0.03^{\mathrm{NS}}$ & $0.04^{\mathrm{NS}}$ \\
Genotype & 9 & $1.36^{* *}$ & $1.92^{* *}$ \\
GCA & 3 & $2.58^{* *}$ & $2.26^{* *}$ \\
SCA & 6 & $0.75^{* *}$ & $1.75^{* *}$ \\
Year $\times$ genotype & 18 & $0.09^{* *}$ & $0.12^{\text {NS }}$ \\
Year $\times$ GCA & 6 & $0.14^{* *}$ & $0.11^{\text {NS }}$ \\
Year $\times$ SCA & 12 & $0.07^{* *}$ & $0.13^{\text {NS }}$ \\
Error & 54 & 0.02 & 0.13
\end{tabular}

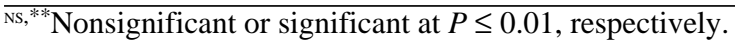


Table 4. Model and diallel ANOVA for visual carotenoid values for size 2 fruit in a four parent cucumber half-diallel with parents in 1991, 1992, and 1993

\begin{tabular}{lcccc}
\hline \hline & & \multicolumn{3}{c}{ Mean square } \\
\cline { 3 - 5 } Source & df & 1991 & 1992 & 1993 \\
\hline Rep & 2 & $0.08^{\mathrm{NS}}$ & $0.01^{\mathrm{NS}}$ & $0.01^{\mathrm{NS}}$ \\
Genotype & 9 & $0.30^{* *}$ & $0.46^{* *}$ & $0.80^{* *}$ \\
GCA & 3 & $0.37^{* *}$ & $0.76^{* *}$ & $1.73^{* *}$ \\
SCA & 6 & $0.26^{* *}$ & $0.31^{* *}$ & $0.33^{* *}$ \\
Error & 18 & 0.04 & 0.01 & 0.02 \\
\end{tabular}

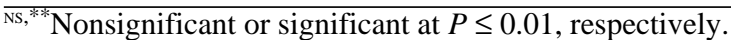

converted to numerical values (Table 2). Before statistical analysis of diallel results was possible, numerical values were assigned to the visually scored color classes for each diallel experiment. Parents P101 and P104 had the highest carotenoid content of size 2 and size 4 fruit, respectively, and none of their hybrids had comparable levels.

Diallel Characterstics. Highly significant $(P<0.01)$ genotypic differences were observed for carotenoid values in size 2 and size 4 fruit across years of the half diallel experiment (Table $3)$. Year and year $\times$ genotype were also highly significant $(P<$ 0.01 ) for size 2 fruit, but was not for size 4 fruit, indicating the importance of environment on the expression of pigmentation in size 2 fruit.

Both general combining ability (GCA) and specific combining ability (SCA), made highly significant $(P<0.01)$ contributions to the genetic variation for carotenoid pigmentation in size 2 and size 4 fruit (Table 3). The GCA mean squares were 3.4 times as large as the SCA mean squares for size 2 fruit, while these values were roughly equivalent for size 4 fruit. These results indicate that in this material both additive and nonadditive genetic effects played an important role in the inheritance of carotenoid pigmentation in size 4 fruit whereas nonadditive variation was less important in size 2 fruit. While year $\times$ GCA and year $\times$ SCA interactions were highly significant $(P<0.01)$ for size 2 fruit, they were not for size 4 fruit.

To better understand these year effects on size 2 fruit, diallel analyses were also performed separately for each individual year (Table 4). The relative contributions of replicate between years and genotype between years were comparable although replicate effects were larger and genotype effects were smaller in 1991 for size 2 fruit than in 1992 and 1993. This year-to-year variation for size 2 (less mature) cucumber color follows the same pattern as for carrot (Daucus carota L.), where Banga and de Bruyn (1968) noted that early in maturity, color differences were greater between years.

Considering the genetic contributions of individual parents to cucumber color (Tables 5 and 6), P100 and P104 had small negative GCA values for size 2 fruit, $\mathrm{P} 105$ had a greater negative effect, and P101 had a larger positive effect. P100 and P101 had small positive GCA values for size 4 fruit. P104 had a large positive effect on size 4 fruit color whereas P105 had a comparable negative effect. The significant year $\times$ GCA interaction for size 2 fruit was due to more extreme positive values for P101 and negative values for P104 and P105 in 1993 than in 1991.

Specific combining ability trends were similar in size 2 and size 4 fruit where parental values were positive while hybrid combinations were usually negative (Tables 5 and 6). SCA values were largest for P101 and its hybrids for size 2 fruit whereas P101, P104, and their hybrids had the largest SCA values for size 4 fruit.
Year $\times$ SCA interactions for size 2 fruit were significant but followed no particular pattern in comparing SCA values for 1991, 1992, and 1993 (data not presented). Size 4 Wisconsin SMR 18 $x$ XIS derivatives were outstanding in that the range of carotenoid content extended much higher than in size 2 fruit or 'Addis' $x$ XIS derivatives. This higher range in observed color is most comparable to that noted in descriptions of the original XIS as grown in China (Chen et al., 1994, Qi et al., 1983; Yang et al., 1991).

An evaluation of reciprocal crosses for the three-parent (P101, P104, and P105) complete diallel was performed in 1991 and 1993. No reciprocal cross differences were found for size 2 or size 4 fruit (data not presented) to indicate that nuclear gene action controls cucumber carotenoid content while non-Mendelian effects were minimal.

The method 2, model 1 analysis used above is more appropriate for this situation because the diallel was performed early in the selection process before genotypes were fixed and ongoing population improvement is necessary. However, we also performed diallel analysis using Griffing's experimental method 4, model 1, a fixed effects model which does not include parents. This analysis revealed greatly reduced mean squares for genotype effects, for overall GCA and SCA effects, and for individual combining ability values (data not presented) to confirm the overwhelming influence of the parents included in the diallel analysis.

\section{Discussion}

Through the introgression of elite U.S. pickling cucumber germplasm with XIS, a landrace from south central China which

Table 5. General combining ability for carotenoid content in a four parent cucumber half-diallel, with parents, in 1991, 1992, and 1993.

\begin{tabular}{lcrrrc}
\hline \hline & $\begin{array}{c}\text { Size } 2 \\
\text { over }\end{array}$ & \multicolumn{3}{c}{ Size 2 } & $\begin{array}{c}\text { Size 4 } \\
\text { over }\end{array}$ \\
\cline { 3 - 5 } Parent & 3 years & 1991 & 1992 & 1993 & 3 years \\
\hline P100 & -0.07 & -0.06 & -0.07 & -0.07 & 0.01 \\
P101 & 0.32 & 0.21 & 0.30 & 0.45 & 0.01 \\
P104 & -0.08 & -0.03 & -0.08 & -0.14 & 0.24 \\
P105 & -0.17 & -0.12 & -0.15 & -0.24 & -0.26 \\
\hline
\end{tabular}

Table 6. Specific combining ability for carotenoid content in a four parent cucumber half-diallel, with parents, in 1991, 1992, and 1993.

\begin{tabular}{ccccc}
\hline & \multicolumn{4}{c}{ Male parent } \\
\cline { 2 - 5 } Female parent & P100 & P101 & P104 & P105 \\
\hline P100 & & & & \\
size 2 & 0.12 & & & \\
size 4 & $0.29^{*}$ & & & \\
P101 & & & & \\
size 2 & $-0.28^{* *}$ & $0.43^{* *}$ & & \\
size 4 & $-0.30^{*}$ & $0.46^{* *}$ & & \\
P104 & & & & \\
size 2 & -0.05 & $-0.22^{*}$ & 0.09 & \\
size 4 & $-0.26^{*}$ & $-0.55^{* *}$ & $0.55^{* *}$ & \\
P105 & & & & 0.11 \\
size 2 & 0.09 & $-0.38^{* *}$ & 0.08 & 0.18 \\
size 4 & -0.02 & -0.06 & $-0.27^{*}$ &
\end{tabular}

${ }^{* * * *}$ Significantly different from zero at $P \leq 0.05$ or 0.01 , respectively. 
is orange-fleshed when mature, it has been possible to develop orange-fleshed cucumber populations that contain carotenoids in both small cucumber sizes for pickling and in mature fruit. Moll and Stuber (1974) suggested that use of the diallel for early generation testing of segregating materials extracted from a population is most valuable as a tool for selecting materials with favorable general combining ability from which elite breeding populations may be synthesized. The present study supported this suggestion.

Results of the diallel analysis for XIS $x$ elite U.S. pickling materials illustrated very good performance of the parents per se, with almost all hybrid combinations performing far below both parents for carotenoid content. The pale color of most hybrids, relative to their parents, suggests that the favorable allelic combinations for orange flesh pigmentation were recessive and noncomplementing in hybrids.

The diallel analysis revealed sizeable positive GCA for P101 (derived from XIS x 'Addis'), for immature size 2 fruit (Tables 5 and 6). The ability of P101 to express fruit pigmentation in size 2 fruit was a fortunate and unexpected development in our breeding for carotenoid pigmentation, because orange color in immature cucumbers has not previously been noted in the most commonly consumed stage of cucumbers in North America (Tatlioglu, 1993). Early expression of carotenoid pigmentation may occur in the exocarp and mesocarp of summer squash and pumpkins with the precocious $B$ gene (Navazio and Simon, unpublished data). P104, derived from XIS x SMR 18, had sizeable positive GCA values for mature fruit color (Tables 5 and 6).

Observation of significant GCA and SCA for size 2 fruit (Table 3 ) indicated that both additive and nonadditive effects were important for cucumber pigment variation but that typical selection procedures which emphasize additive effects should be successful in improving carotenoid pigmentation in size 2 fruit (Moll and Stuber, 1974). The orange pigmentation observed in P101, and its progeny in our work has appeared in all 3 years of evaluation. Although there was a highly significant year, year $\times$ GCA, and year $\times$ SCA effect (Tables 3 and 4), the mean total carotenoid levels remained stable across the 3 years (Table 4). Further improvement of P101 material may be best served by population improvement as suggested by Moll and Stuber (1974). Options available for possible population improvement that may preserve favorable allelic combinations would be recurrent selection or small population mass selection. Simon et al. (1989) successfully raised carotene levels in carrot using a very small initial number of $F_{1}$ roots in forming a population, to minimize the possible pernicious effects of recombination.

Cucumber, one of the most important vegetable crops worldwide, is well adapted to cultivation in the lowland tropics and is widely grown in these regions. With the quantity of cucumbers consumed annually in various cultures it is possible that the amounts of provitamin A carotenoids that we have introduced into cucumber, if accepted, could contribute to reduction of vitamin A deficiency. To assure implementation of carotenoidrich cucumber production, other important attributes such as fruit shape and quality, spine color, and disease resistance must be considered in the breeding process.

\section{Literature Cited}

Banga, O. and J.W. de Bruyn. 1968. Effect of temperature on the balance between protein synthesis and carotenogenesis in the roots of carrot. Euphytica 17:168-172.

Chen, J.F., S.G. Zhang, and X.G. Zhang. 1994. The Xishuangbanna gourd (Cucumis sativus var. xishuangbannesis Qi et Yuan), a traditionally cultivated plant of the Hanai people, Xishuangbanna, Yunan, China. Cucurbit Genet. Coop. Rept. 17:18-20.

Food and Agricultural Organization (FAO) 1998. Cucumbers and gherkins, table 55. Production yearbook 52. Food Agr. Org., Rome. p. 130 131 .

Griffing, B. 1956. Concept of general and specific combining ability in relation to diallel crossing systems. Austral. J. Biol. Sci. 9:463-493.

Kooistra, E. 1971. Inheritance of fruit flesh and skin colours in powdery mildew resistant cucumbers (Cucumis sativus L.). Euphytica 20:521523.

Moll, R.H. and C.W. Stuber. 1974. Quantitative genetics. Adv. Agron. 26:277-313.

Munger, H.M. 1988. Adaptation and breeding of vegetable crops for improved human nutrition, p. 177-184. In: B. Quebedeaux and F.A. Bliss (eds.). Horticulture and human health. Prentice Hall, Englewood Cliffs, N.J.

Qi, C.Z., Z.Z. Yuan, and Y.X. Li. 1983. A new type of cucumber, Cucumis sativus L. var. xishuangbannanesis Qi et Yuan. (English summary only). Acta Hort. Sinica 10:259-262.

SAS Institute Inc. 1990. SAS user's guide: Statistics. 4th ed. SAS Inst. Inc., Cary, N.C.

Senti, F.R. and R.L. Rizek. 1975. Nutrient levels in horticultural crops. HortScience 10:243-246.

Simon, P.W. 1990. Carrots and other horticultural crops as a source of provitamin A carotenes. HortScience 25:1495-1499.

Simon, P.W. and J.P. Navazio. 1997. Early orange mass 400, early orange mass 402, and late orange mass 404: High-carotene cucumber germplasm. HortScience 32:144-145.

Simon, P.W. and X.Y. Wolff. 1987. Carotenes in typical and dark orange carrots. J. Agr. Food Chem. 35:1017-1022.

Simon,P.W., X.Y.Wolff, C.E.Peterson, D.S.Kammerlohr, V.E. Rubatzsky, J.O. Strandberg, M.J. Basset, and J.M. White. 1989. High carotene mass carrot population. HortScience 24:174-175.

Snedecor, G.W. and W.G. Cochran. 1980. Statistical methods. 7th ed. Iowa State Univ. Press, Ames.

Staub, J.E. and J. Bacher. 1997. Cucumber as a processed vegetable, p. 129-193. In: D.S. Smith, J.N. Cash, W.-K. Nip, and Y.H. Hui (eds.). Processing vegetables. Technomic Publ. Co., Lancaster, Pa.

Steenbock, H. and E.G. Gross. 1919. Fat-soluble vitamine. II. The fatsoluble vitamine content of roots, together with some observations on their water-soluble vitamine content. J. Biol. Chem. 40:501-531.

Tatlioglu. T. 1993. Cucumber Cucumis sativus L., p. 197-234. In: G. Kalloo and B. O. Bergh (eds.). Genetic improvement of vegetable crops. Pergamon Press, Oxford, United Kingdom.

The British Colour Council and The Royal Horticultural Society. 1938. Horticultural colour chart. The Brit. Colour Council and The Royal Hort. Soc. London.

U.S. Department of Agriculture. 1966. U.S. standard for grades of pickles. Section 52. U.S. Dept. Agr., Washington, D.C.

Walker, J.C. 1958. Two new pickling cucumber varieties resistant to scab and mosaic. Plant Dis. Rptr. 42:1337-1338.

World Bank. 1993. Public health, p. 72-107. In: D. T. Jamison (ed). World development report 1993. Oxford Univ. Press, New York.

World Health Organization (WHO). 1995. Global prevalence of vitamin A deficiency. MDIS Working Paper 2. World Health Organization, Geneva, Switzerland.

Yang, S.L., H. Pu, and P.Y. Liu. 1991. Preliminary studies on Cucumis sativus var. xishuangbannanesis. Cucurbit Genet. Coop. Rpt. 14:29-31.

Ye, X., S. Al-Babili, A. Kloti, J.Zhang, P. Lucca, P. Beyer, and I. Potrykus. 2000. Engineering the provitamin A (b-carotene) biosynthetic pathway into (carotenoid-free) rice endosperm. Science 287:303-305. 